\title{
Collaborative Governance Antara Pemerintah Desa dengan Warga Desa dalam Pengelolaan Cerobong Sampah dan Bank Sampah di Desa Kramatwatu
}

\author{
Ranti Meidita Lestari ${ }^{1}$ \\ Ilmu Pemerintahan, Universitas Sultan Ageng \\ Tirtayasa \\ rantimeidita1199@gmail.com \\ Tazkiya Farahnisa ${ }^{2}$ \\ Ilmu Pemerintahan, Universitas Sultan Ageng \\ Tirtayasa \\ tazkiyafarah99@gmail.com
}

\author{
E-ISSN (2721-0642) \\ Recieved: \\ June 102020 \\ Revised: \\ December 112020 \\ Accepted: \\ December 142020 \\ Doi Number \\ https://doi.org/10.37950/ijd.v2i3.57
}

\begin{abstract}
This study aims to analyze the Collaborative Governance process and find out the factors that influence the collaboration process in the chimney and waste bank program in Kramatwatu Village. The research method used is descriptive method with a qualitative approach. The results showed that collaborative governance in the chimney and waste bank program in Kramatwatu Village had been going well, only one process that had not gone well was commitment, seen from the indicators of collaborative governance according to Ansel and Gash, namely face-to-face dialogue (face to face), building trust (trust building), commitment to the process (commitment to process), shared understanding (share understanding), and intermediate outcomes. Judging from the commitment process in Kramatwatu Village, it has not been going well, it is located in RW 01 and also RW 04, which has a responsibility for the chimney that is not responsible so that the waste reduction is not optimal. The factors that influence the collaboration process are initial conditions, facilitative leadership, and institutional design.
\end{abstract}

Keywords: collaborative governance, chimney, garbage bank 


\section{Abstrak}

Penelitian ini bertujuan untuk menganalisis proses Collaborative Governance dan mengetahui faktor-faktor yang memengaruhi proses kolaborasi dalam program cerobong sampah dan bank sampah di Desa Kramatwatu. Metode penelitian yang digunakan adalah metode deskriptif dengan pendekatan kualitatif. Hasil penelitian menunjukkan bahwa collaborative governance dalam program cerobong sampah dan Bank sampah di Desa Kramatwatu sudah berjalan dengan baik, hanya saja salah satu proses yang belum berjalan dengan baik yaitu komitmen, dilihat dari indikator proses collaborative governance menurut Ansel dan Gash, yaitu dialog tatap muka (face to face), membangun kepercayaan (trust building), komitmen terhadap proses (commitment to process), pemahaman bersama (share understanding), dan hasil antara (Intermediate outcomes). Dilihat pada proses komitmen di Desa Kramatwatu belum berjalan dengan baik ini terletak pada RW 01 dan juga RW 04 yang memiliki penanggungjawab atas cerobong sampah yang kurang bertanggungjawab sehingga kurang maksimalnya pengurangan sampah. Adapun faktor yang mempengaruhi proses kolaborasi yaitu kondisi awal, kepemimpinan fasilitatif, dan desain institusioanal.

Kata kunci : collaborative governance, cerobong sampah, bank sampah

\section{Pendahuluan}

Di Indonesia, permasalahan sampah telah menjadi masalah serius yang membutuhkan solusi berkelanjutan, tidak hanya di perkotaan, di pedesaan pun ditemukan. Tumpukkan sampah yang tidak terurus akan menjadi sumber utama pencemaran lingkungan, seperti menimbulkan bau tidak sedap dan menjadi tempat bersarangnya penyakit, terutama pemukiman warga. Pencemaran lingkungan yang disebabkan oleh sampah ini timbul akibat minimnya fasilitas pembuangan sampah, termasuk transportasi pengangkut sampah ke Tempat Pembuangan Akhir (TPA) di setiap desa. Berangkat dari masalah tersebut, perlu adanya kesadaran dari pemerintah maupun masyarakat untuk mencari solusi tepat untuk pengelolaan sampah. Sampah dibagi menjadi dua jenis, yaitu jenis sampah organic dan sampah non-organik. Dengan demikian, sampah dapat dikelola dengan cara dimanfaatkan kembali dan dengan membakar sampah atau teknik incinerator sehingga dapat mengurangi pencemaran lingkungan. Teknik pengelolaan sampah melalui daur ulang atau pemanfaatan kembali yang dapat direalisasikan dengan cara menciptakan bank sampah. Di mana, sampahsampah non-organik dipilah kemudian diolah kembali sehingga menjadi barang yang mempunyai nilai guna. Lain halnya dengan teknik incinerator, teknik ini terbagi menjadi dua tipe, yaitu dilakukan sebagai pemusnah sampah yang kemudian asap dari hasil pembakaran dibuang begitu saja. Teknik incinerator yang kedua ialah dilakukan dengan memanfaatkan asap atau panas yang dihasilkan dari pembakaran sampah tersebut untuk dimanfaatkan sebagai pembangkit tenaga listrik.

Menurut Dirjen Cipta Karya, 2011, salah satu penerapan 3R (reduce, reuse, recycle) adalah bank sampah, yang mana pada pengelolaannya sampah dikelola pada sumbernya di tingkat masyarakat. Pada dasarnya, bank sampah dilakukan dengan prinsip rekayasa sosial untuk menarik partisipasi masyarakat dalam pengelolaan sampah. Karena pelaksanaan bank sampah memiliki nilai eknomis yang cukup tinggi, sehingga masyarakat dapat teredukasi untuk memilah sampah dan mengelolanya di 
bank sampah. Selain memiliki nilai ekonomis, bank sampah juga bermanfaat untuk masyarakat berupa pembinaan terkait daur ulang sampah dan juga mendapat kesempatan kerja.

Selain pengelolaan melalui bank sampah, pengelolaan teknik incinerator atau pembakaran sampah. Teknik incinerator ini dilakukan dengan cara menghancurkan sampah menggunakan tungku atau cerobong sampah dan menghasilkan gas yang steril dan ramah lingkungan, yang kemudian dapat langsung dibuang ke tanah.

Seperti halnya di Desa Kramatwatu, tumpukan sampah yang tidak berkurang bahkan terus menerus bertambah seiring dengan tingginya pertumbuhan populasi manusia. Selain itu, ketersediaan truk sampah yang masih terbatas dan minimnya intensitas waktu pengangkutan sampah yang dilakukan di Desa Kramatwatu. Maka, dalam hal ini, pemerintah Desa berkewajiban untuk memberikan pelayanan kebersihan kepada masyarakat, terutama di dalam pengelolaan sampah. Namun, di sisi lain, pemerintah Desa sebagai lembaga penyelenggara kebijakan juga membutuhkan partisipasi aktif dari warga Desa agar tercipta collaborative governance yang saling menguntungkan.

Melihat kondisi yang ada di Desa Kramatwatu terkait permasalahan sampah membuat salah satu warga memiliki inovasi di mana beliau meciptakan suatu cerobong sampah yang dipasang didepan rumahnya untuk dapat digunakan sebagai tempat pembakaran sampah. Dari inisiatif tersebut akhirnya diajukanlah kepada Pemerintah Desa Kramatwatu dalam rapat MusrenbangDes sebagai salah satu masukan warga untuk dapat menjalankan inovasi tersebut. Kemudian, Pemerintah Desa meyetujui masukan tersebut untuk melaksanakan cerobong sampah berikut Bank Sampah di Desa Kramatwatu. Pengadaan cerobong sampah ini disebar di setiap RW Desa Kramatwatu, lain halnya dengan Bank Sampah. Bank Sampah ini dilaksanakan di kantor Desa Kramatwatu yang kemudian hasil dari bank sampah tersebut diperjualbelikan di BUMDes Desa Kramatwatu.

Pengembangan cerobong sampah dan bank sampah ini diharapkan mampu mengurangi permasalahan sampah di Desa Kramatwatu berbasis pemberdayaan masyarakat. Salah satu pemberdayaan masyarakat dalam program ini adalah dengan masyarakat sebagai aktor pencetus inovasi sebagai solusi permasalahan sampah dan menjadikan masyarakat berpartisipasi aktif dalam pelaksanaan bank sampah dan cerobong sampah. Hasil dari pemberdayaan masyarakat tersebut yang diharapkan yaitu masyarakat dapat meningkatkan produktifitas dalam sektor wirausaha.

Dalam tulisan kali ini, penulis akan membahas mengenai awal mula collaborative governance antara Pemerintah Desa dan warga Desa Kramatwatu dalam pengelolaan bank sampah dan cerobong sampah bisa terjadi, proses dari collaborative governance, tujuan dari collaborative governance, kesesuaian antara hasil dari pelaksanaan collaborative governance dengan tujuan awal pembentukkan bank sampah dan cerobong sampah, serta kendala yang dalam pelaksanaan collaborative governance tersebut.

\section{Kerangka Teori \\ Paradigma Governance}

Dalam paradigma Governance dijelaskan mengenai lembaga pelaksana tidak hanya menjadi tanggungjawab pemerintah. Sebab pemerintah mulai sadar bahwa kesanggupan pemerintah dalam mengelola negara semakin terbatas, baik dari SDM, teknologi, anggaran dan kemampuan mengelola dalam menyelesaikan masalah yang 
berhubungan dengan kebutuhan masyarakat umum. Tidak hanya itu, demokrasi juga mengharuskan pemerintah untuk membuka ruang seluas-luasnya bagi bagi Civil Society Organizations (CSOs) dan pihak swasta dalam merumuskan serta melaksanakan suatu kebijakan publik. Pada paradigma governance terdapat tiga actor, yaitu government, private sector, dan civil society. Ketiga actor tersebut memiliki peran sebagai eksekutor dalam pembangunan. Dalam pelaksanaannya, porsi ketiga actor tersebut saling berhubungan agar dapat melengkapi satu sama lain.

Menurut Chema pada Keban (2003:38), Governance diartikan sebagai sistem nilai dan kelembagaan yang mengurus urusan poltik, sosial, ekonomi yang dirancang melalui hubungan pemerintah masyarakat dan sektor swasta.

Berdasarkan pandangan ahli di atas menunjukan bahwa terdapat urusan publik yang dikelola oleh pemerintah Bersama aktor-aktor lain yang ada di dalam 'Governance' itu sendiri sehingga pemerintah tidak mendominasi penyelenggaraan pemerintahan yang menyangku kepentingan-kepentingan publik.

\section{Kolaborasi}

Kolaborasi diartikan sebagai kerjasama antar individu, antar organisasi, dan antar institusi untuk mencapai tujuan yang tidak bisa dicapai secara independent. Kolaborasi menurut Samatupang, adalah menyatukan beberapa pihak yang membawa kepentingan berbeda yang bertujuan untuk membangun visi yang sama, menciptakan consensus terkait masalah yang terjadi, menghadirkan jalan keluar untuk masalah tersebut dan memprioritaskan nilai-nilai kolektif yang nantinya akan menciptakan keputusan Bersama yang menguntungkan semua pihak.

Hal yang sama dicetuskan oleh Schrage (1990) kolaborasi yaitu hubungan yang dibangun dalam rangka menciptakan solusi untuk menyelesaikan suatu masalah dalam keadaan terbatas, misalnya keterbatasan informasi, ruang dan waktu.

Dari dua pernyataan ahli, dapat kita ketahui bahwa kolaborasi merupakan proses kolektif untuk menciptakan solusi dari suatu masalah yang berangkat dari keterbatasan yang dialami individu-individu.

\section{Collaborative Governance}

Menurut Ansell dan Gash (2007:543), Collaborative governance adalah cara baru dalam penyelenggaraan pemerintahan yang melibatkan para stakeholder menyatu dalam forum yang sama untuk mencapai kesepakatan bersama. Kemudian Ansell dan Gash lebih lanjut menyatakan bahwa Collaborative Governance merupakan konsep penyesuaian dalam penyelenggaraan pemerintahan yang di dalamnya terdapat lebih dari satu institusi publik dan aktor non pemerintahan untuk melaksanakan proses perumusan kebijakan publik yang bersifat formal dan berfokus pada kesepakatan bersama, berikut pengimplementasian dan pengelolaan program kebijakan publik.

Dalam pernyataan di atas Ansell dan Gash menekankan enam dasar penilaian terhadap Collaborative Governance pertama forum tersebu bersifat resmi yang dicetuskan oleh institusi publik. Kedua, pihak yang ikut berperan serta dalam forum tersebut harus meliputi aktor non pemerintah. Ketiga, partisipan harus terlibat langsung dalam perumusan kebijakan. Keempat, forum harus bersifat formal dan dilaksanakan pertemuan secara rutin. Kelima, keputusan yang diambil harus berdasarkan kesepakatan bersama. Keenam, kolaborasi ini harus beorientasi pada kepentingan publik. 
Latar belakang munculnya Collaborative Governance adalah semakin berkembangnya masyarakat, semakin kompleks pula masalah yang dihadapi pemerintah. Yang mana pemerintah juga memiliki berbagai keterbatasan untuk memecahkan masalah tersebut, dan tidak dapat dipungkiri pemerintah membutuhkan kolaborasi dengan aktor-aktor non pemerintah.

Proses collaborative governance menurut Ansell dan Gash (2007:558-561) yaitu:

\section{Face to Face dialogue}

Collaborative Governance diawali dari dialog tatap muka (face to face dialogue) secara langsung yang melibatkan setiap stakeholder. Karena collaborative governance ditinjau dari proses, maka dialog tatap muka harus dilaksanakan yang bertujuan untuk mencari peluang kebijakan yang dapat menguntungkan semua pihak. Pentingnya dialog tatap muka ini bertujuan untuk mengurangi antagonisme dan sikap tidak menghargai yang kemungkinan besar akan timbul pada stakeholder yang terlibat.

\section{Trust Building}

Dalam pelaksanaan collaborative governance pasti akan timbul rasa tidak percaya antar stakeholder maka dari itu, trust building harus dilakukan secepat mungkin dimulai saat proses kolaborasi pertama dilaksanakan. Membangun kepercayaan (trust bulding) perlu dilakukan agar para stakeholder tidak saling mengedepankan kepentingan pribadi maupun kepentingan kelompok.

\section{Commitment to process}

Setiap stakeholder harus memiliki komitmen yang kuat untuk meminimalisir kemungkinan terburuk dari proses kolaborasi.

\section{Share Understanding}

Pada proses awal dilakukannya collaborative governance, para stakeholder harus saling berbagi pemahaman mengenai apa yang akan mereka capai dari prosses kolaborasi yang dilakukan. Hal tersebut dapat di implementasikan melalui saling berbagi pemahaman mengenai misi bersama, visi bersama, tujuan Bersama, kepentingan, dan ideologi yang sama.

\section{Intermediate Outcomes}

Collaborative governance itu sendiri akan terlaksana ketika tujuan dan keuntungan dari kolaborasi tersebut bersifat nyata. Maka, terlebih dahulu perlu dirancang dengan serius mengenai tujuan dan keuntungan dilaksanakannya collaborative governance.

Sebagai salah satu masalah kompleks yang terjadi di tengah masyarakat dan sulit dipecahkan adalah masalah lingkungan, terkhusus masalah sampah. Berbagai masalah turut muncul akibat dari sampah di Desa Kramatwatu yang tidak terkoordinir dengan baik. Seperti munculnya berbagai macam penyakit, bau tidak sedap, tumpukkan sampah yang menyumbat saluran air, sampai dengan masalah bencana banjir. Oleh karena itu, dengan dijelaskannya latar belakang, pengertian, sampai dengan proses pelaksanaan collaborative governance, diharapkan hal tersebut mampu diterapkan dengan baik demi mencari dan merealisasikan solusi yang tepat untuk mengatasi masalah sampah tersebut. Meski terlihat ideal, masih banyak yang meragukan efektivitas dalam landasan teori maupun pelaksanaan collaborative governance ini.

Pengelolaan bank sampah dan cerobong sampah melalui proses kolaborasi ini sangat mungkin untuk bisa dilaksanakan, walaupun hal ini dinilai membutuhkan waktu, tenaga dan pendanaan yang tidak sedikit. Dalam upaya pengelolaan bank sampah dan cerobong sampah ini melibatkan 2 (dua) undur, yaitu,

a. Pemerintah Desa Kramatwatu, Kecamatan Kramatwatu, Kabupaten Serang. 
b. Seluruh masyarakat Desa Kramatwatu yang terdiri dari 6 (enam) RW.

Kolaborasi antara dun stakeholder ini dinilai akan potensial, apabila melaksanakan tahapan collaborative governance dengan baik, dimulai dari Face to face dialogue, trust building, commitment to process, share understanding, hingga pada intermediate outcomes.

\section{Gambar 1.}

Model Collaborative Governance Ansell \& Gash

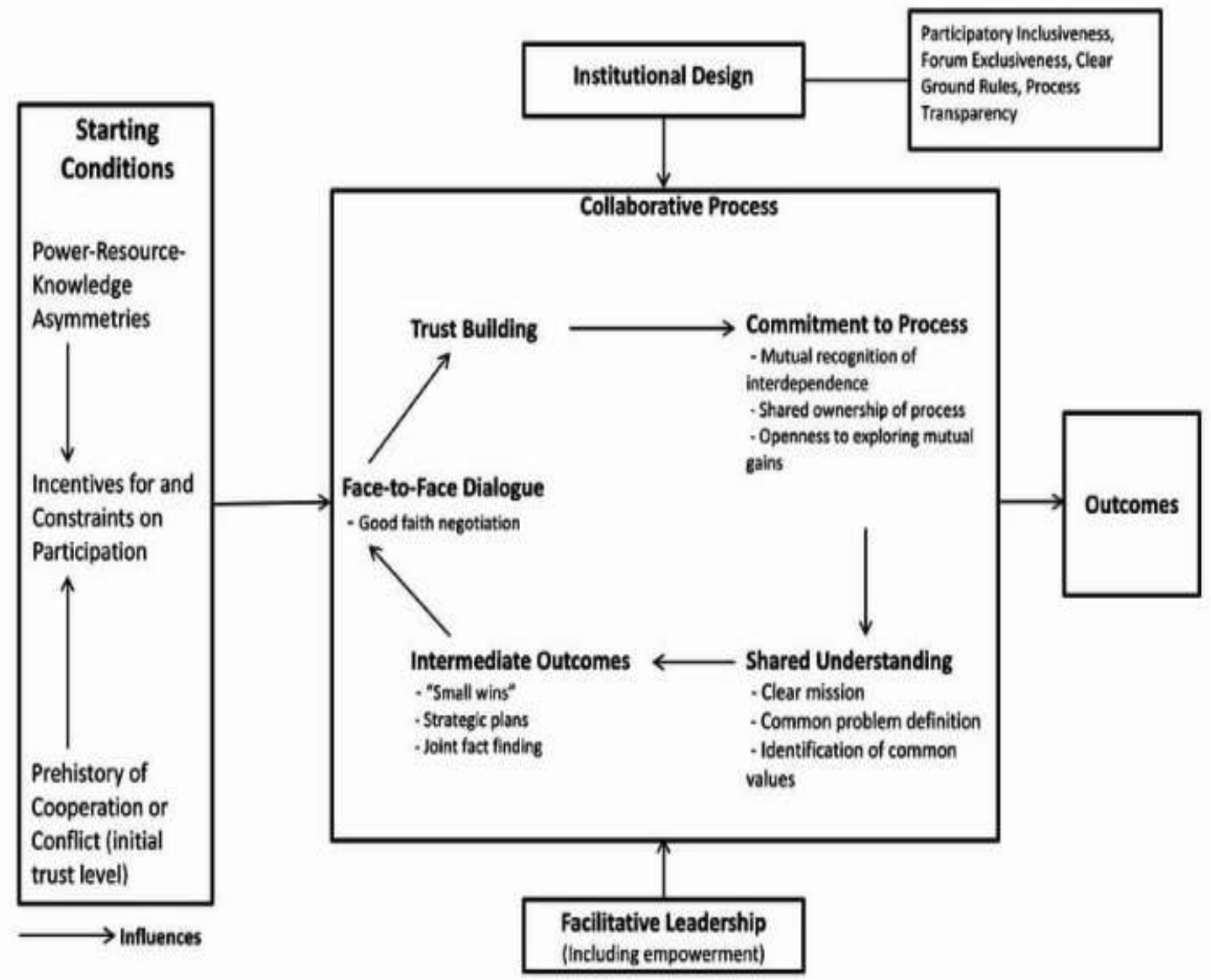

Sumber : Ansell and Gash. 2008. Collaborative Governance in Theory and Practice Journal of Public Administration Research and Theory Vol. 8 (4).

Pada gambar 1 tergambar bahwa awal mula kolaborasi terjadi di latarbelakangi oleh starting conditions, yang merupakan ketidakseimbangan sumber daya dan mengakibatkan hambatan pada partisipasi juga karena adanya sejarah konflik dari proses kerjasama sebelumnya. Kolaborasi adalah salah satu bentuk kerjasama dan interaksi yang selalu berulang. Diawali dengan membangun kepercayaan dalam lingkup para stakeholder guna menciptakan komitmen bersama untuk melaksanakan proses kolaborasi, kemudian para stakeholder saling berbagi pemahaman mengenai apa, bagaimana, mengapa proses kolaborasi tersebut dilakukan demi mendapatkan hasil antara. Dalam kolaborasi juga perlu adanya dialog tatap muka, dialog tatap muka ini 
merupakan bagian dari wadah untuk membangun kepercayaan. Rangkaian ini akan terus berulang dalam proses kolaborasi.

Proses kolaborasi juga membutuhkan desain institusional, yang di dalamnya terdapat ketentuan hokum dan peraturan yang mengacu pada cara para stakeholder menerapkan dan mematuhi aturan yang ada. Dalam desain institusional harus mempunyai dukungan dari pemimpin yang mendukung sarana untuk melancarkan proses koloborasi sehingga dapat menghasilkan manfaat untuk masyarakat luas.

\section{Metode Penelitian}

Dalam penelitian kali ini, penulis menggunakan metode penelitian deskriptif dengan pendekatan kualitatif. Menurut Miles dan Huberman, analisi data adalah kegiatan menganalisis data kualitatif yang dilakukan secara interaktif dan berlangsung terus menerus (Sugiyono, 2014:91).

Fokus penelitian kali ini adalah: (1) Awal mula collaborative governance antara Pemerintah Desa dengan Warga Desa Kramatwatu dalam pengelolaan bank dan cerobong sampah bisa terjadi, (2) Proses dari collaborative governance, (3) Tujuan dari collaborative governance, (4) Kesesuaian anatara hasil dari pelaksanaan collaborative governance dengan tujuan awal pembentukan bank sampah dan cerobong sampah, (5) Kendala yang ditemukan dalam pelaksanaan collaborative governance tersebut.

Lokasi penelitian ini di Desa Kramatwatu, Kabupaten Serang. Cerobong sampah berada di setiap RW, yang mana ada 6 (enam) RW di Desa Kramatwatu. Sedangkan tempat produksi Bank Sampah terletak di Kantor Desa Kramatwatu.

Pengumpulan data pada penelitian ini dilakukan dengan observasi, wawancara dan dokumentasi. Kemudian, instrumen penelitiannya adalah catatan lapangan dan pedoman wawancara. Analisis data dengan menggunakan model interaktif menurut Miles dan Huberman yaitu reduksi data, penyajian data, dan penarikan kesimpulan.

\section{Hasil dan Diskusi}

\section{Proses Collaborative Governance Pemerintah Desa dengan Warga Desa Kramatwatu Dialog Tatap Muka (Face to face)}

Kolaborasi merupakan proses kolektif yang melibatkan para pemangku kepentingan, maka diperlukan komunikasi intensif melalui dialog tatap muka untuk membicarakan mengenai peluang kebijakan yang dapat berguna bagi semua pihak. Dialog tatap muka ini dianggap penting karena bertujuan untuk mengurangi antagonisme yang kemungkinan besar akan timbul pada seluruh stakeholder yang terlibat.

Dialog tatap muka dalam proses kolaborasi ini dilakukan sesuai kebutuhan, baik secara formal maupun secara informal. Proses ini dilakukan melalui musrenbangdes dan road show yang menjelaskan mengenai tata cara, manfaat, dan hal yang dihasilkan dari pelaksaan cerobong sampah dan Bank sampah. Inovasi pengelolaan sampah ini di inisiasi oleh pak Budi yang merupakan salah satu warga Desa Kramatwatu.

Dialog tatap muka ini tidak hanya membas tentang kesepakatan bersama tetapi juga sebagai sarana untuk berbagi pemahaman antar stakeholder. Untuk mencapai hasil yang sesuai dengan kesepakatan bersama, maka perlu adanya komitmen jangaka Panjang untuk saling menjaga kepercayaan. Setelah disampaikan pemahaman mengenai proses mengenai kebijakan maka akan terbangun kepercayaan pada masyarakat. 


\section{Membangun Kepercayaan (Trust building)}

Dalam menjalankan proses kolaboratif untuk pengelolaan sampah di Desa Kramatwatu antara pemerintah desa dengan warga desa, terdapat cara-cara dalam membangun kepercayaan dengan cara saling menghormati dan saling menghargai satu sama lain antara pemerintah desa dan warga desa. Keterbukaan dalam menangani permasalahan sampah yang terjadi di Desa Kramatwatu, merupakn hal yang dibutuhkan juga dalam membangun rasa kepercayaan.

Salah satu warga Desa Kramatwatu yang merupakan penggagas dari inovasi cerobong sampah dan bank sampah yaitu Bapak Budi, melalui musrenbangdes melakukan presentasi yang memaparkan solusi terhadap permasalahan sampah yang kian memburuk di desa dan kurangnya truk pengangkut sampah. Dalam presentasinya, Pak Budi menjelaskan, bahwa cerobong sampah dan bank sampah merupakan cara yang efektif dalam mengatasi permasalahan sampah di Dessa Kramatwatu. Pemerintah Desa menyetujui solusi yang ditawarkan oleh Pak Budi, sehingga tumbuh rasa percaya bahwa solusi tersebut dapat dilakukan. Setelah itu, Pak Budi melakukan presentasi-presentasi berikutnya di setiap RW, dari RW 01 hingga ke RW 06. Semua masyarakat di setiap RW percaya juga bahwa solusi ini dapat mengatasi masalah sampah di Desa Kramatwatu. Dapat dikatakan bahwa proses membangun kepercayaan dalam proses kolaborasi itu sangat penting.

\section{Komitmen terhadap Proses (Commitment to Process)}

Dalam menjalankan kolaborasi, diperlukan komitmen yang kuat bagi setiap pemangku kepentingan pada suatu proses kolaborasi. Factor penting yang dapat menentukan keberhasilan maupun kegagalan sutau kolaborasi adalah komitmen. Bila komitmen yang dijalankan oleh pemangku kepentingan tidak berjalan dengan baik, maka akan timbul permasalahan.

Di Desa Kramatwatu mempunyai komitmen, bahwa setiap cerobong sampah yang terletak di masing-masing RW mempunyai penanggungjawab. Pemangku kepentingan yang menjadi penanggungjawab telah disepakati bahwa sangat berpengaruh pada proses tata kelola kolaborasi. Hal ini dapat dilihat pada Desa Kramatwatu, terdapat penanggungjawab yang tidak melakukan komitmen dengan baik, seperti pada RW 04 dan RW 06. Hal ini menimbulkan permasalahan, yaitu belum maksimalnya pengurangan sampah melalui cerobong sampah, yang pada awalnya memiliki target $20 \%$ dalam pengurangan sampah, namun pada realitanya hanya $5 \%$ saja.

Pada Bank sampah komitmen yang dijalankan juga kurang baik, hal ini dapat terlihat bahwa proses pengumpulan dan pembuatan produk Bank sampah jarang dilaksanakan. Warga desa yang awalnya memiliki komitmen untuk mengurangi penumpukan sampah menjadi lupa bahwa tujuan awlnya seperti apa hal ini karena adanya sikap gengsi untuk mengumpulkan sampah ke Pemerintah Desa. Selain itu juga dikarenakan imbalan ke warga desa dalam mengumpulkan sampah satu karung hanya bernilai 5.000 rupiah hal itu dirasa tidak sebanding dengan apa yang telah dilakukan.

\section{Pemahaman Bersama (Share Understanding)}

Setiap tahapan proses pengelolaan sampah di Desa Kramatwatu ini telah dilakukan melelui proses pemahaman Bersama. Melalui musrenbangdes, pak Budi yang merupakan pengagagas cerobong sampah dan bak sampah ini menyampaikan 
keresahannya tentang penumpukkan sampah di sepanjang jalan Desa Kramatwatu. Kemudian beliau memberikan saran inovasi pengelolaan sampah yaitu cerobong sampah dan Bank sampah. Beliau menyampaikan tata cara dari pelaksaan pengelolaan sampah tersebut, yaitu dengan prinsip 3R. Setelah diajukan dan disetujui oleh Pemerintah Desa, Pemerintah Desa berencana membangun cerobong sampah di setiap RW dari mulai RW 01 hingga RW 06 dan menempatkan bank sampah di kantor Desa. Kemudian produk dari Bank sampah tersebut diperjual belikan di BUMDes Keramatwatu. Setelah melalui musrenbangdes, dengan membawa hasil kesepakatan, kemudian dilaksanakan road show ke setiap RW kemudian dijelaskan maksud dan tujuan dari kebijakan pengelolaan sampah, melalui kolaborasi antara Pemerintah Desa dan warga Desa, diataranya:

1. Mewujudkan lingkungan sehat dan bersih dari sampah, yang mempunyai target $20 \%$ pengurangan penumpukan sampah

2. Menjadikan sampaha daur ulang sebagai sumber daya yang memiliki nilai ekonomis.

3. Meningkatkan partisipasi aktif masyarakat terhadap upaya pengurangan sampah di Desa Kramatwatu.

4. Mewujudkan keharmonisan antara masyarakat desa dan Pemerintah Desa Kramatwatu.

\section{Hasil antara (Intermediate Outcomes)}

1. Penumpukan sampah di Desa Kramatwatu sudah berkurang $5 \%$ dan dapat ditangani dengan adanya cerobong sampah yang dapat membakar sampah non recyle. Namun hal ini masih jauh dari tujuan awal pengurangan sampah 20\%, karena tingkat kesadaran masyarakat dalam memilah sampah masih rendah.

2. Telah terbentuknya cerobong sampah di setiap RW, dari RW 01 hingga RW 06. Namun masih terdapat beberapa penempatan cerobong sampah yang tidak disetujui warga di salah satu RW.

3. Telah terbentuk Bank sampah dan sudah tersedia alat pencacah sampah berikut pencetak produk. Pengalokasian produk ke BUMDes pun sudah terlaksana. Hal ini masih terkendala kesadaran masyarakat yang masih rendah untuk rutin mengumpulkan sampah recyle dan pelaksanaan pembuatan produk hanya berjalan dalam kurun waktu 1 atau 3 bulan sekali, sehingga pemasran produknya tidak konsisten.

4. Terciptanya kepedulian masyarakat untuk berpartisipasi aktif dalam kebersihan lingkungan seperti membakar sampah di cerobong sampah setiap sore dan memilah sampah.

5. Terciptanya keharmonisan antara Pemerintah desa dengan warga desa. 
Volume $x$, Issue $x$, Month Year

Gambar 2. Cerobong sampah di Kantor Desa Kramatwatu

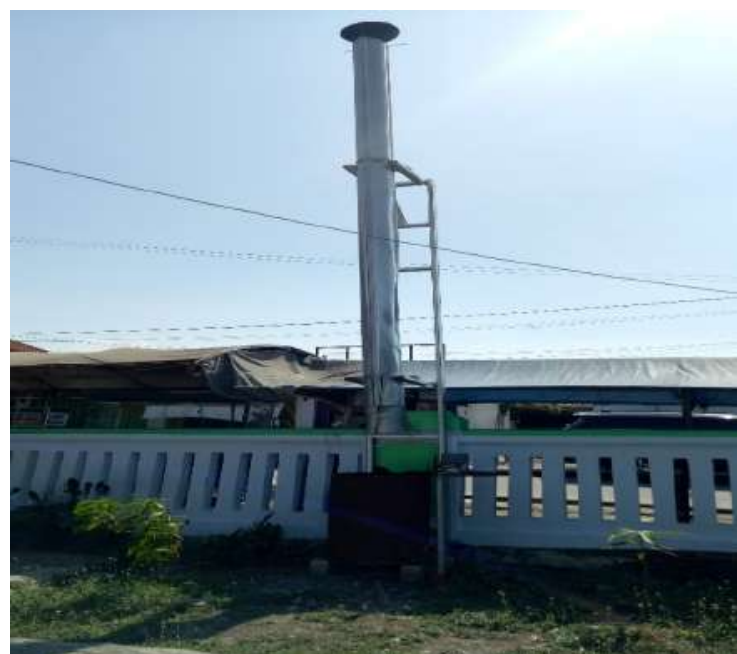

Sumber: Dokumentasi Peneliti

Gambar 3. Cerobong sampah di RW 01

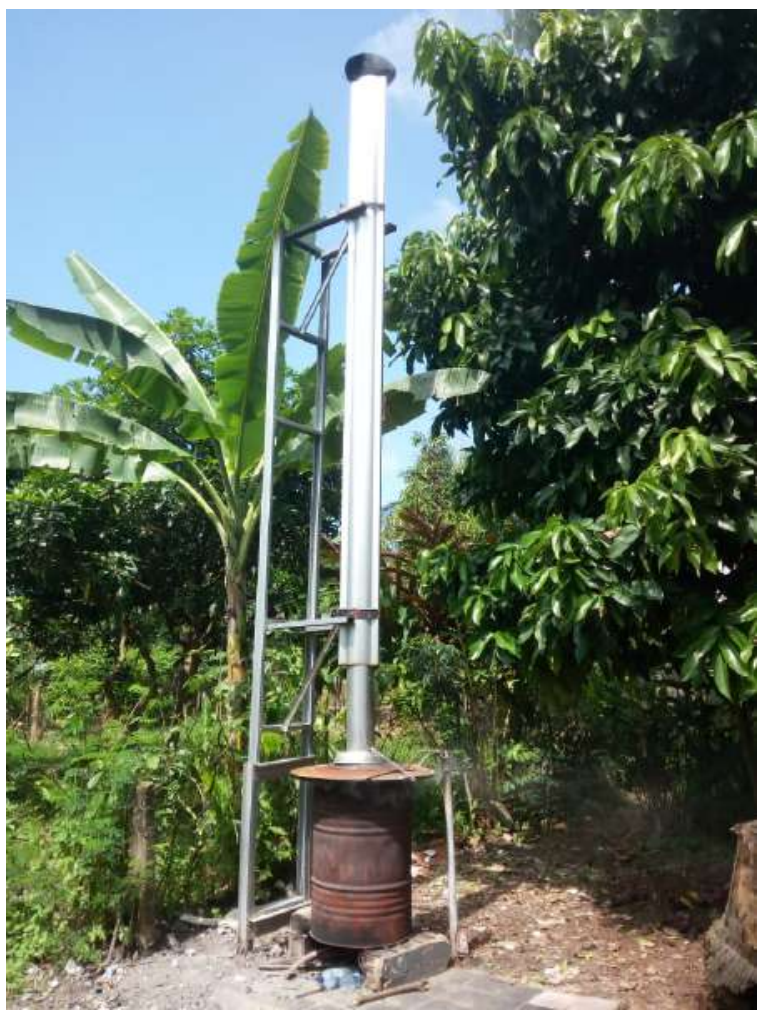

Sumber: Dokumentasi Peneliti 
Gambar 4. Cerobong sampah di RW 02

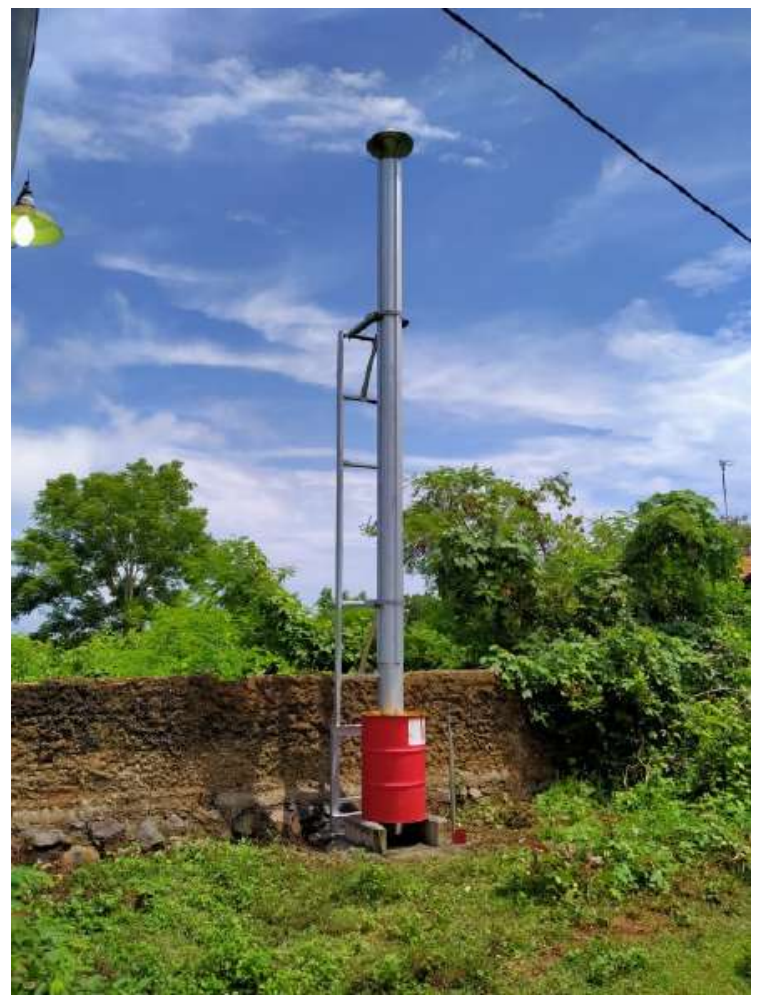

Sumber: Dokumentasi Peneliti

Gambar 5. Cerobong sampah di RW 03

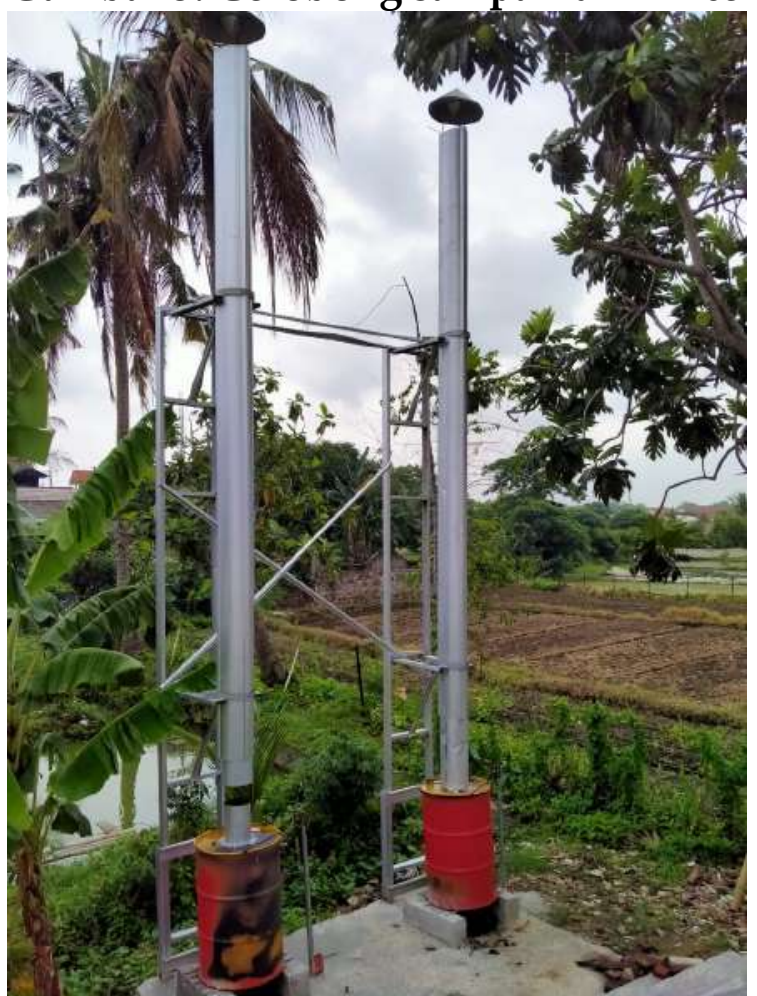

Sumber: Dokumentasi Peneliti

Gambar 6. Cerobong sampah di RW 05 
Volume $x$, Issue $x$, Month Year

http://hk-publishing.id/ijd-demos

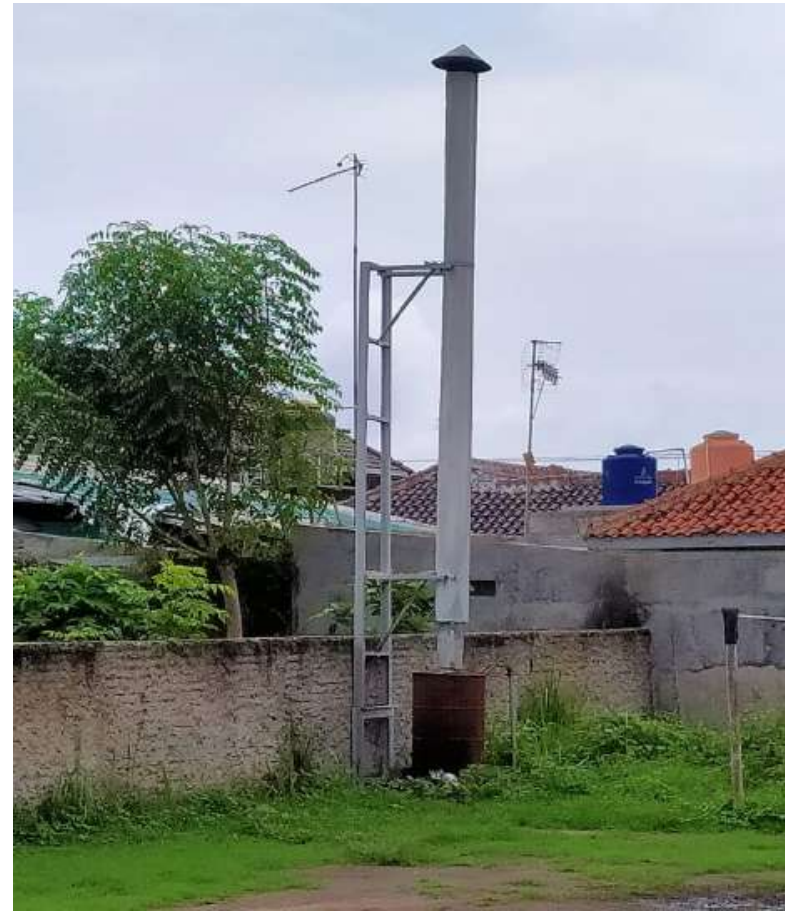

Sumber: Dokumentasi Peneliti

Gambar 7. Alat cerobong sampah yang belum dipasang.

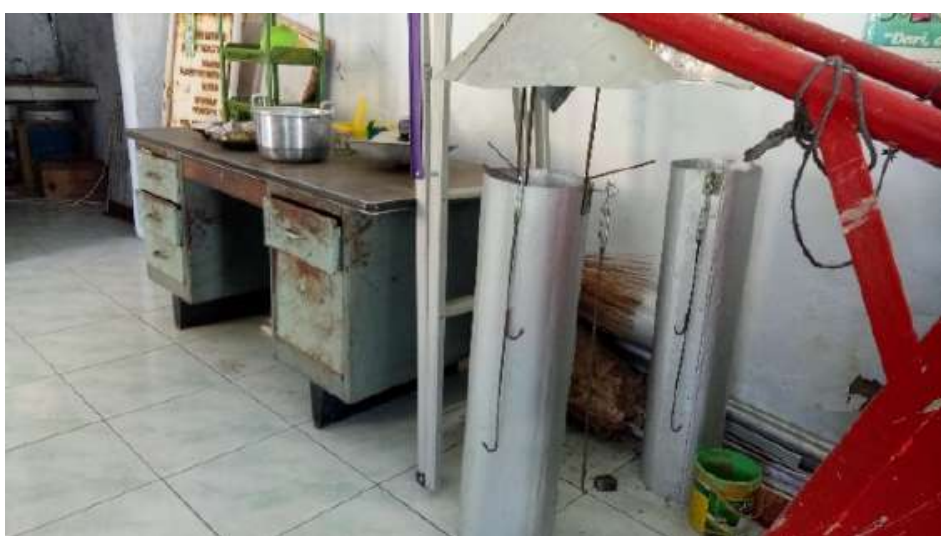

Sumber: Dokumentasi Peneliti

Gambar 8. Alat pencacah sampah plastik. 


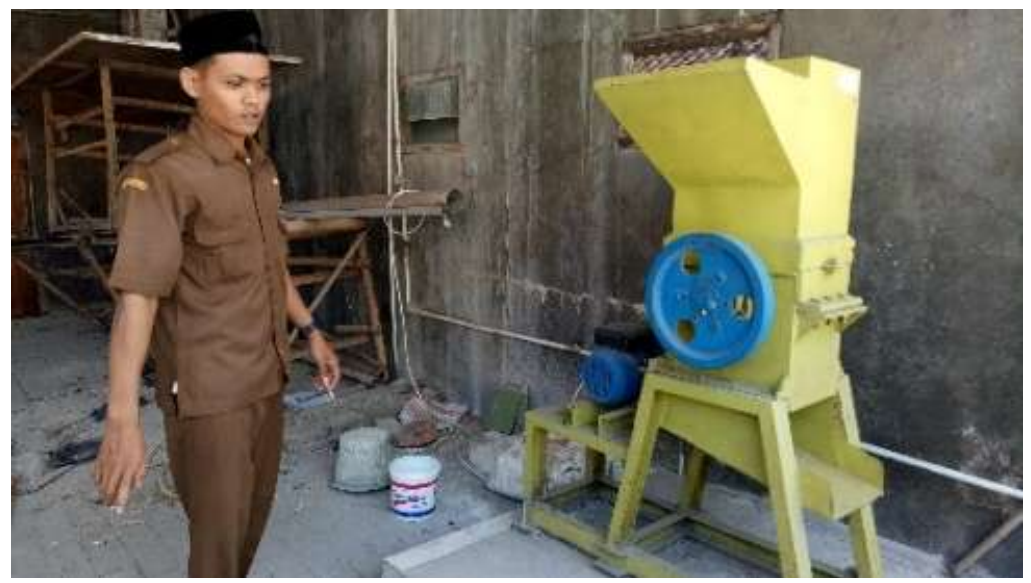

Sumber: Dokumentasi Peneliti

\section{Gambar 9. Mesin jahit untuk memproduksi produk Bank Sampah}

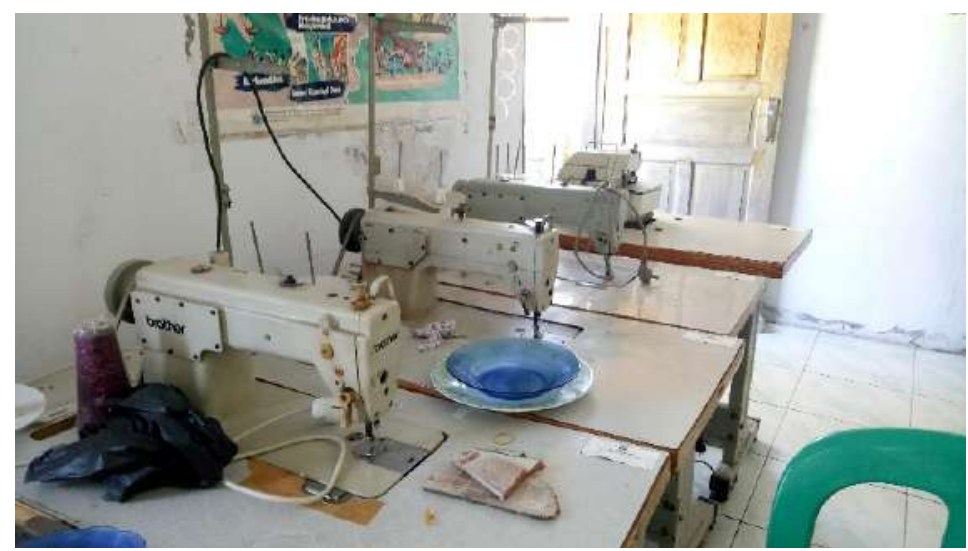

Sumber: Dokumentasi Peneliti

\section{Faktor-faktor yang mempengaruhi proses kolaborasi}

\section{Kondisi Awal}

Kondisi awal adalah suatu kondisi yang menggambarkan ketika kolaborasi belum terjadi. Chris Ansell dan Allison Gash (2007) membagi 3 kondisi awal, yaitu ketidakseimbangan sumber daya, sejarah masa lalu dan insentif. Pada penelitian ini, latar belakang terjadinya collaborative governance adalah karena terbatasnya truk pengangkut sampah di Desa Kramatwatu. Kemudian sejarah sebelum adanya cerobong sampah dan bank sampah adalah penumpukan sampah di sepanjang jalan Desa Kramatwatu. Jika dilihat dari sisi insentif, cerobong sampah dan bank sampah diharapkan mampu mengatasi permaslahan penumpukan sampah di Desa Kramatwatu.

\section{Kepempimpinan Fasilitatif}

Kepemimpinan Fasilitatif berperan penting dalam proses collaborative governance. Hal ini diperlukan karena untuk mengarahkan para pemangku kepentingan dan mengajak agar semua kator dapat terlibat dalam proses kolaborasi. Dalam proses kolaborasi penanganan sampah melalui cerobong sampah dan bank sampah di Desa Kramatwatu ini kepemimpinan fasilitatif yang dominan dilakukan oleh Kepala Desa 
Kramatwatu dan salah satu warga desa yaitu pak Budi sebagai penggagas dari Cerobong sampah dan Bank sampah di Desa Kramatwatu. Fungsi dari Kepala Desa dalam fasilitasi kepemimpinan ialah maerangkul, memberdayakan, dan melibatkan pemangku kepentingan dan memobilisasi sumber daya manusia yang ada untuk ikut berkolaborasi. Sedangkan fungsi dari aktor penggagas berfungsi melaksanakan membangun kepercayaan pada masyarakat, sosialisasi terkait cerong sampah dan bank sampah, memonitor proses pelaksanaan cerobong sampah dan Bank sampah, dan juga berkoordinasi denga Pemerintah Desa.

\section{Desain institusional}

Desain institusional berorientasi pada aturan dasar yang mengatur proses collaborative governance yang jelas dan konsisten. Berdasarkan Undang-undang nomor 18 tahun 2008 yang mendasari pengelolaan sampah di Desa Kramatwatu. Pada undang-undang nomor 18 tahun 2008 tentang pengelolaan sampah bahwa pengelolaan sampah bertujuan untuk meningkatkan kesehatan masyarakat dan kualitas lingkungan serta menjadikan sampah sebagai sumber daya yang bermanfaat. Selain itu, komitmen untuk menjalankan collaborative governance dalam pengelolaan sampah di Desa Kramatwatu juga menjadi dasar terlaksananya proses kolaborasi.

This section consists of research findings and discussion. Every finding should be supported by sufficient data. Then, research findings should be able to answer the research question or hypothesis stated earlier in the introduction.

\section{Kesimpulan}

Collaborative governance antara Pemerintah Desa dan warga Desa di Desa Kramatwatu dalam mengatasi permasalahan sampah melalui Bank sampah dan cerobong sampah ini dilatarbelakangi oleh salah satu warga desa yaitu pak Budi. Beliau melakukan presentasi dalam kegiatan musrenbangdes yang memeberikan solusi untuk mengatasi permasalahan sampah yang akhirnya disetujui oleh Pemerintah Desa, sehingga proses kolaborasi ini berjalan.

Dalam proses kolaborasi yang terjadi antara Pemerintah Desa dan warga Desa di Desa Kramatwatu ini sudah efektif, namun masih terdapat kekurangan yaitu pada proses komitmen. Pada proses komitmen telah disepakati bahwa masing-masing RW di Desa Kramatwatu memiliki penanggungjawab atas cerobong sampah. Namun komitmen ini belum berjalan dengan baik di RW 01 dan RW 04 yang berdampak kurang maksimalnya pengurangan sampah melalui cerobong sampah yang pada awalnya memiliki target $20 \%$ namun pada realitanya hanya dapat mengurangi sampah sebanyak $5 \%$ saja. Kemudian proses komitmen pada Bank sampah masih belum terlaksana dengan baik hal ini dikarenakan sikap gengsi dari masyarakat desa untuk mengumpulkan sampah dan harga yang dirasa tidak sebanding pada saat mengumpulkan sampah melalui Bank sampah, sehingga berdampak pada pembuatan produk Bank sampah yang jarang dilakukan.

\section{Referensi}

Anshell and Gash. 2008. Collaborative Governance in Theory and Practice. Journal of Public Administration Research and Theory. Vol. 4 (8) 
Asteria, Dona dan Heru Heruman. 2015. Bank Sampah sebagai Alternatif Strategi Pengelolaan Sampah Berbasis Masyarakat di Tasikmalaya. Jurnal Manusia dan Lingkungan. Vol. 23 (1).

Bagus, Trisaksono. 2002. Pengelolaan dan Pemanfaatan Sampah Menggunakan Teknologi Incenerator. Jurnal Teknologi Lingkungan Vol. 3 (1).

Fauziah, Hana. 2018. Analisis Collaborative Governance dalam Pengelolaan Bank Sampah di Kabupaten Bandung. Skripsi: Ilmu Administrasi Publik, FISIP, UNPAR.

Handoko, Tito. Syofian. M. Y. Tiyas Tinov. 2018. Collaborative Governance dalam Pengendalian Pencermaran Lingkungan oleh Aktivitas Industri pada Daerah Aliran Sungai (DAS) Siak di Kota Pekanbaru. Jurnal Administrative Reform. Vol. 6 (3).

Rinaldoa, Edwin dan Amy Yayuk Sri Rahayu. 2019. Penanganan Sampah Secara Kolaboratif antara Masyarakat dan Petugas Penanganan Prasarana dan Sarana Umum (PPSU) tingkat Kelurahan. Jurnal Inspirasi. Vol. 10(1).

Rosyadi, Slamet dan Erna Lestianingrum. 2013. Permodelan Sampah Pemukiman Berbasis Manajemen Kolaborasi. Jurnal Pembangunan Pedesaan. Vol. 13 (2).

Saputro, Yusa Eko. Kismartini dan Syafrudin. 2015. Pengelolaan Sampah Berbasis Masyarakat Melalui Bank Sampah. Indonesian Journal of Conversation. Vol. 04 (1).

Schrage, M. 1990. Shared Minds: The New Technologies of Collaboration.

Sufianti, Ely. 2011. Perencanaan Kolaborasi dalam Pengelolaan Sampah sebagai Upaya Pembangunan Lingkungan yang Berkelanjutan. Jurnal Ilmu Administrasi. Vol VIII (3). 